University of Nebraska - Lincoln

DigitalCommons@University of Nebraska - Lincoln

Biological Systems Engineering: Papers and

Publications

Biological Systems Engineering

$7-2021$

\title{
Impact of Irrigation Technologies on Withdrawals and Consumptive Use of Water
}

\author{
Eric Wilkening \\ University of Nebraska-Lincoln, ewilkening@huskers.unl.edu \\ Derek M. Heeren \\ University of Nebraska-Lincoln, derek.heeren@unl.edu \\ Douglas R. Hallum \\ University of Nebraska-Lincoln, dhallum2@unl.edu \\ Jennifer Schellpeper \\ Nebraska Department of Natural Resources, jennifer.schellpeper@nebraska.gov \\ Derrel Martin \\ University of Nebraska-Lincoln, derrel.martin@unl.edu
}

Follow this and additional works at: https://digitalcommons.unl.edu/biosysengfacpub

Part of the Bioresource and Agricultural Engineering Commons, and the Civil and Environmental

Engineering Commons

Wilkening, Eric; Heeren, Derek M.; Hallum, Douglas R.; Schellpeper, Jennifer; and Martin, Derrel, "Impact of Irrigation Technologies on Withdrawals and Consumptive Use of Water" (2021). Biological Systems Engineering: Papers and Publications. 765.

https://digitalcommons.unl.edu/biosysengfacpub/765

This Article is brought to you for free and open access by the Biological Systems Engineering at DigitalCommons@University of Nebraska - Lincoln. It has been accepted for inclusion in Biological Systems Engineering: Papers and Publications by an authorized administrator of DigitalCommons@University of Nebraska Lincoln. 


\title{
Impact of Irrigation Technologies on Withdrawals and Consumptive Use of Water
}

\author{
Eric Wilkening ${ }^{1}$, Undergraduate Research Assistant \\ Derek M. Heeren ${ }^{1}$, Associate Professor and Water for Food Global Institute Faculty Fellow \\ Doug Hallum², Survey Hydrogeologist \\ Jennifer Schellpeper ${ }^{3}$, Integrated Water Management Division Manager \\ Derrel L. Martin', Professor Emeritus and Water for Food Global Institute Faculty Fellow \\ ${ }^{1}$ Department of Biological Systems Engineering, University of Nebraska-Lincoln \\ ${ }^{2}$ Conservation and Survey Division, University of Nebraska-Lincoln \\ ${ }^{3}$ Department of Natural Resources, State of Nebraska \\ Written for presentation at the \\ 2021 Annual International Meeting \\ ASABE Virtual and On Demand \\ July 12-16, 2021
}

\begin{abstract}
Developments in irrigation technologies have subsequently led to increases in irrigation application efficiency, including conversion from surface to sprinkler irrigation, variable rate irrigation (VRI), and low energy precision application. However, while these increases in application efficiency may reduce water withdrawals and/or diversions (from groundwater or surface water), they may not necessarily translate to additional water being available for future or downstream use. Consumptive use of water, water consumed and not returned to the local or sub-regional watershed, is not necessarily impacted by increased application efficiency, but is an important metric in conserving water for other uses. One recent irrigation technology is VRI; while conventional irrigation scheduling methods generally do not consider terrain or root zone available water variability across a particular field site, VRI can account for such spatial variability. This research evaluated several site-years of field VRI research data in an attempt to quantify potential reductions in pumping and consumptive use from irrigation technology. The previously developed consumptive use ratio (change in consumptive use / change in irrigation water applied) provides a useful metric to estimate potential consumptive use reductions for irrigation technologies compared to conventional irrigation. The consumptive use ratio was calculated for different irrigation management scenarios, including VRI (utilizing zone control prescriptions), across four years and two field sites in Eastern and Western Nebraska. Comparing well-managed conventional irrigation scheduling to VRI scheduling, the consumptive use ratio was found to range between $63 \%$ and $77 \%$. When VRI does result in reduced water withdrawals, it likely includes some reduction in both consumptive use and deep percolation of irrigation water. Finally, a theoretical approach was presented to model the marginal consumptive use ratio based on both Cobbs-Douglas and polynomial functions. The marginal consumptive use ratio depends on whether seasonal irrigation is in the deficit irrigation, full irrigation, or over irrigation range.
\end{abstract}

Keywords. Consumptive Use, Consumptive Use Ratio, Irrigation Water Balance, Variable Rate Irrigation

The authors are solely responsible for the content of this meeting presentation. The presentation does not necessarily reflect the official position of the American Society of Agricultural and Biological Engineers (ASABE), and its printing and distribution does not constitute an endorsement of views which may be expressed. Meeting presentations are not subject to the formal peer review process by ASABE editorial committees; therefore, they are not to be presented as refereed publications. Publish your paper in our journal after successfully completing the peer review process. See www.asabe.org/JournalSubmission for details. Citation of this work should state that it is from an ASABE meeting paper. EXAMPLE: Author's Last Name, Initials. 2021. Title of presentation. ASABE Paper No. ---. St. Joseph, MI.: ASABE. For information about securing permission to reprint or reproduce a meeting presentation, please contact ASABE at www.asabe.org/copyright (2950 Niles Road, St. Joseph, MI 49085-9659 USA). ${ }^{1}$ 


\section{Introduction}

In Nebraska and many other areas in the world, irrigation is the largest anthropogenic use of water resources. Optimal use of irrigation water is increasingly necessary to meet future water demands and to meet other economic, environmental, social, and political constraints.

Developments in irrigation technologies have led to increases in irrigation application efficiency (Evett et al., 2020), meaning that a higher percentage of irrigation water is converted to consumptive use by the plants with a lower percentage retained as increased soil moisture, return flow to the groundwater system, or lost to direct evaporation. Examples include conversion from furrow to sprinkler irrigation, variable rate irrigation (VRI), and low energy precision application. These technologies have facilitated the reduction of water withdrawals and/or diversions (from groundwater or surface water) for irrigation and may lead to a variety of benefits, which include decreasing groundwater storage withdrawals, decreasing pumping energy expenses, lowering the frequency/severity of yield loss due to over-irrigation, reducing irrigation runoff on hillslopes, and decreasing nitrate leaching. While these increases in application efficiency may reduce water withdrawals and/or diversions, they may not necessarily translate to additional water being available for future or downstream use.

A common misunderstanding regarding increasingly efficient irrigation technologies is that they uniformly "conserve" water, with reduced pumping or diversion resulting in more water available to future or downstream users. In an inefficient irrigation system, much of the "inefficiency" is water that percolates past the root zone, increases vadose zone water storage, and ultimately recharges the aquifer, increasing groundwater storage (Figure 1). Fields lacking a containment structure may generate runoff that flows into a stream and is available for downstream users. Advancements in irrigation technology may reduce aquifer withdrawals by reducing inefficiencies which previously lead to deep percolation, i.e., reducing aquifer recharge. At the watershed scale, the key concept is consumptive use, i.e., water that is "consumed" (i.e., ET) and is not returned to the water system for re-use by another water user. When examining impacts of irrigation technology changes at the watershed scale, the best way to "conserve" water is to reduce consumptive use (Perry et al., 2009; Grafton et al., 2018). Reducing consumptive use of water is an important means of conserving water for other uses.

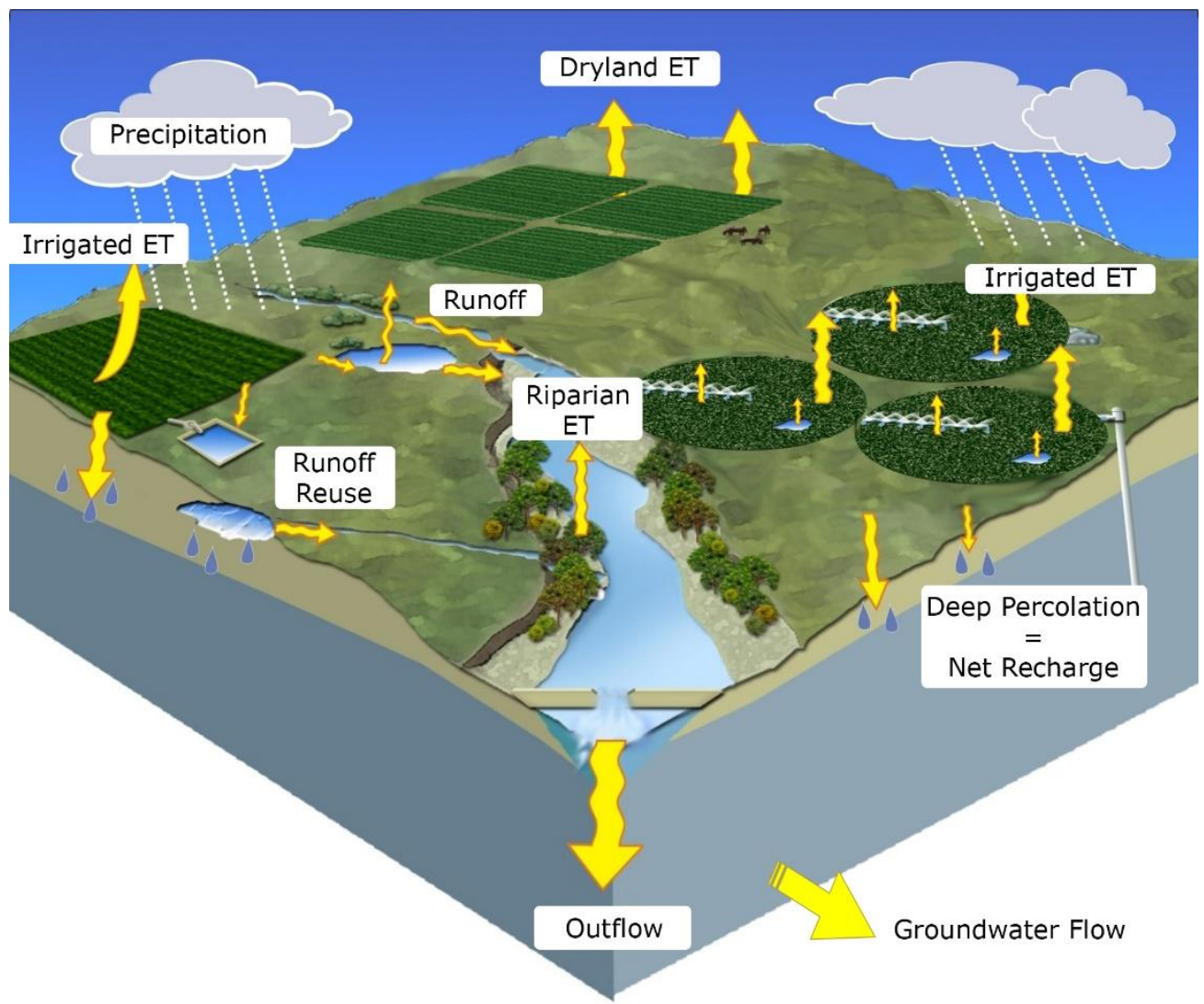

Figure 1. Watershed-scale water balance (adapted from Eisenhauer et al., 2021). Some water "losses" are returned to the watershed. Over the long-term, the only way to increase the amount of water available to downstream users is to decrease consumptive use.

This misunderstanding is often applied to VRI technology. Stakeholders in Nebraska are rightly concerned about groundwater level declines and the subsequent impacts on streamflow. VRI is reported to reduce pumping for irrigation, and it is often assumed that the reduction in groundwater withdrawals will have a positive impact on groundwater levels and 
streamflow. Decision makers who are considering whether to invest in new irrigation technologies (e.g., cost-share) need to have a realistic assessment of the impact of new technologies on water resources, considering both change in withdrawals/diversions/return flows and overall change in consumptive use. In Natural Resources Districts (NRDs) where allocations limit the amount of water that can be pumped for irrigation prevent them from reaching a full crop yield, new technologies may be a tool for producers to maximize yield with a given amount of irrigation. In this case consumptive use is likely increased at the expense of groundwater recharge, deep percolation or runoff that would have otherwise returned to the water system.

The objective of this paper was to 1) provide a conceptual framework for the impact of irrigation technology on consumptive use relative to the yield production function, and 2) to quantify the fraction of pumping reduction that comes from a reduction in consumptive use.

\section{Consumptive Use Defined}

Hydrological conservation is needed when water must be conserved to sustain a fresh water supply or to meet a downstream demand for fresh water. The term "consumptive use" is defined here as water consumed and not returned to the local or sub-regional watershed. A coal power plant that diverts stream water for cooling and returns that water to the same stream is not a consumptive use insofar as the water is available to downstream users (Eisenhauer et al., 2021), except for the typically small direct evaporation component. In general, the largest consumptive use of water in a watershed is ET.

Sometimes this concept is applied to the influence of land use change on ET. For example, ET for an irrigated field compared to the ET the field would have if it was not irrigated. Here, we use the term "consumptive use change" to refer to the change in ET due to land use change. A discussion of the subtleties of consumptive use when changing agricultural production practices is provided in Kranz et al. (2015).

For irrigated fields, the "consumptive use ratio" has been defined as the ratio of the change in consumptive use and the change in irrigation water applied (Martin et al., 2010). The consumptive use ratio can be a useful metric to estimate potential consumptive use reductions for irrigation technologies compared to conventional irrigation.

Some have further categorized consumptive use into "beneficial consumptive use" and "non-beneficial consumptive use" (Perry et al., 2009). The best way to reduce consumptive use is to reduce non-beneficial consumption of water, such as the ET of weeds in a road ditch or the ET of vegetation adjacent to an irrigation canal (Kranz et al., 2015).

The Nebraska Groundwater Management Act defines both beneficial use and consumptive use as follows: Beneficial use means that use by which water may be put to use to the benefit of humans or other species; consumptive use means the amount of water that is consumed under appropriate and reasonably efficient practices to accomplish without waste the purposes for which the appropriation or other legally permitted use is lawfully made.

\section{Theoretical Development}

\section{Functions for Marginal Consumptive Use Ratio}

As crop irrigation is one of the largest users of water resources in Nebraska and around the world (Eisenhauer et al., 2021), quantifying consumptive uses in irrigation is important. Martin et al. $(1984,2010)$ established a series of equations that can be used to quantify the crop yield production function and a consumptive use ratio:

$$
\begin{gathered}
\frac{Y-Y_{n}}{Y_{f}-Y_{n}}=1-\left(1-\frac{d}{d_{f}}\right)^{\frac{1}{\beta}} \\
\beta=\frac{E T_{f}-E T_{n}}{d_{f}}
\end{gathered}
$$

Where:

$$
\begin{aligned}
& Y=\text { yield } \\
& Y_{f}=\text { full yield } \\
& Y_{n}=\text { non-irrigated yield } \\
& d=\text { depth of seasonal irrigation } \\
& d_{f}=\text { depth of seasonal irrigation for full yield } \\
& \beta=\text { consumptive use ratio } \\
& E T_{f}=\text { seasonal ET for full yield } \\
& E T_{n}=\text { seasonal ET for non-irrigated crop. }
\end{aligned}
$$


The primary equation, Equation 1, is a combination of the Cobb-Douglas production function and a linear relationship between crop yield and seasonal evapotranspiration. The equation utilizes parameters with a physical meaning and assumes that the slope of the $Y$-ET curve is equal to the slope of the $Y$ - $d$ curve as $d$ approaches zero. Also, the slope of the $Y$ - $d$ curve becomes zero at $d=d_{f}$. This production function was part of the CROPSIM model which has been used by the Nebraska Department of Natural Resources (2010). Equation 2 gives $\beta$, the fraction of $d_{f}$ which is evapotranspired to produce the full yield. Martin et al. (2010) defined $\beta$ as the water use efficiency at full irrigation; however, this quantity is also used to define the "consumptive use ratio," i.e., the ratio of water consumptively used and leaving the determined system to the total amount of irrigation water used within the system. Figures $2 a$ and $2 b$ illustrate $a$ water flow mass balance for two common types of irrigation systems.

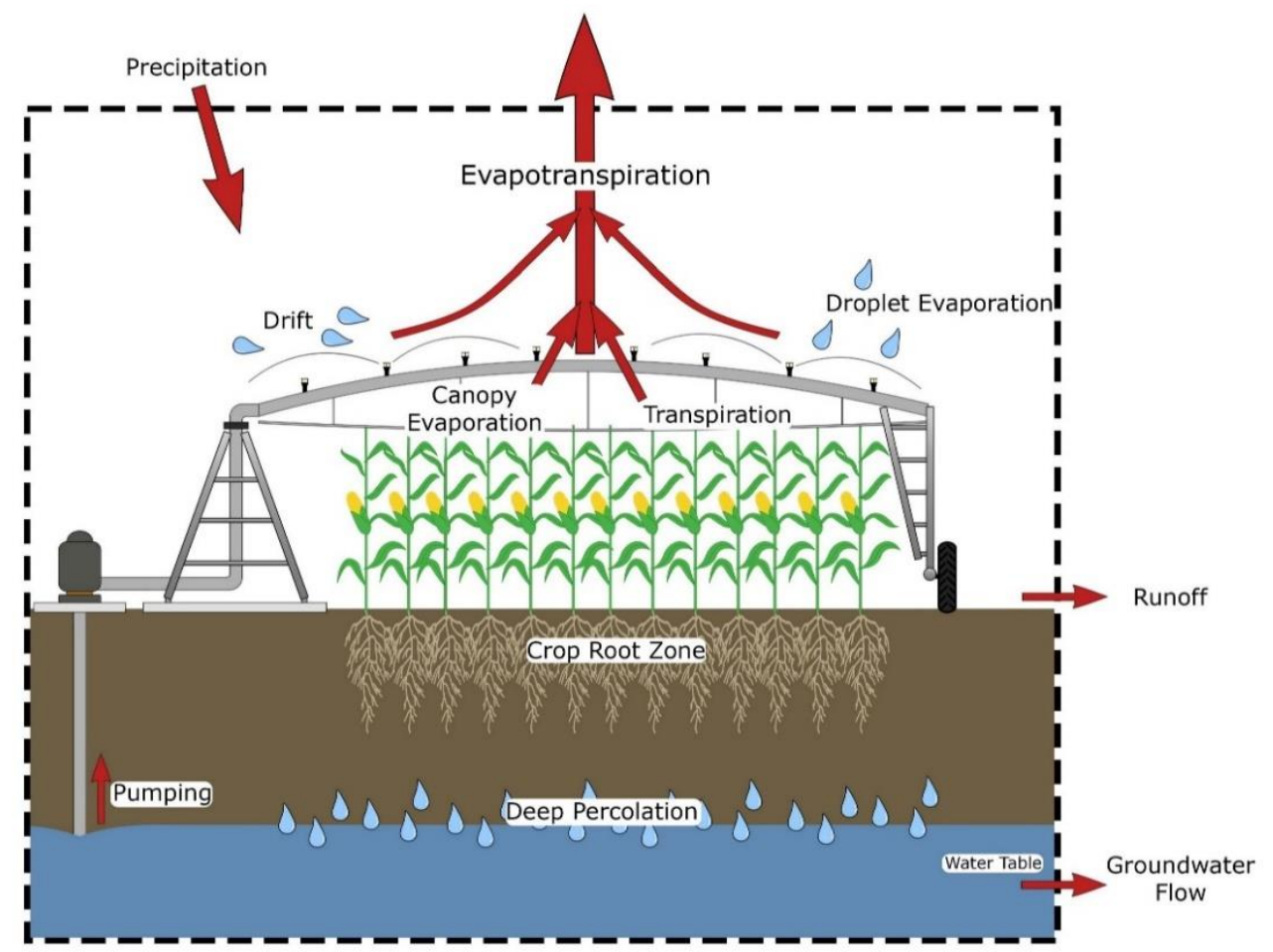

Figure 2a. Illustration of potential water flows for center pivot (sprinkler) irrigation, constrained to a field-level system (adapted from Eisenhauer et al., 2021).

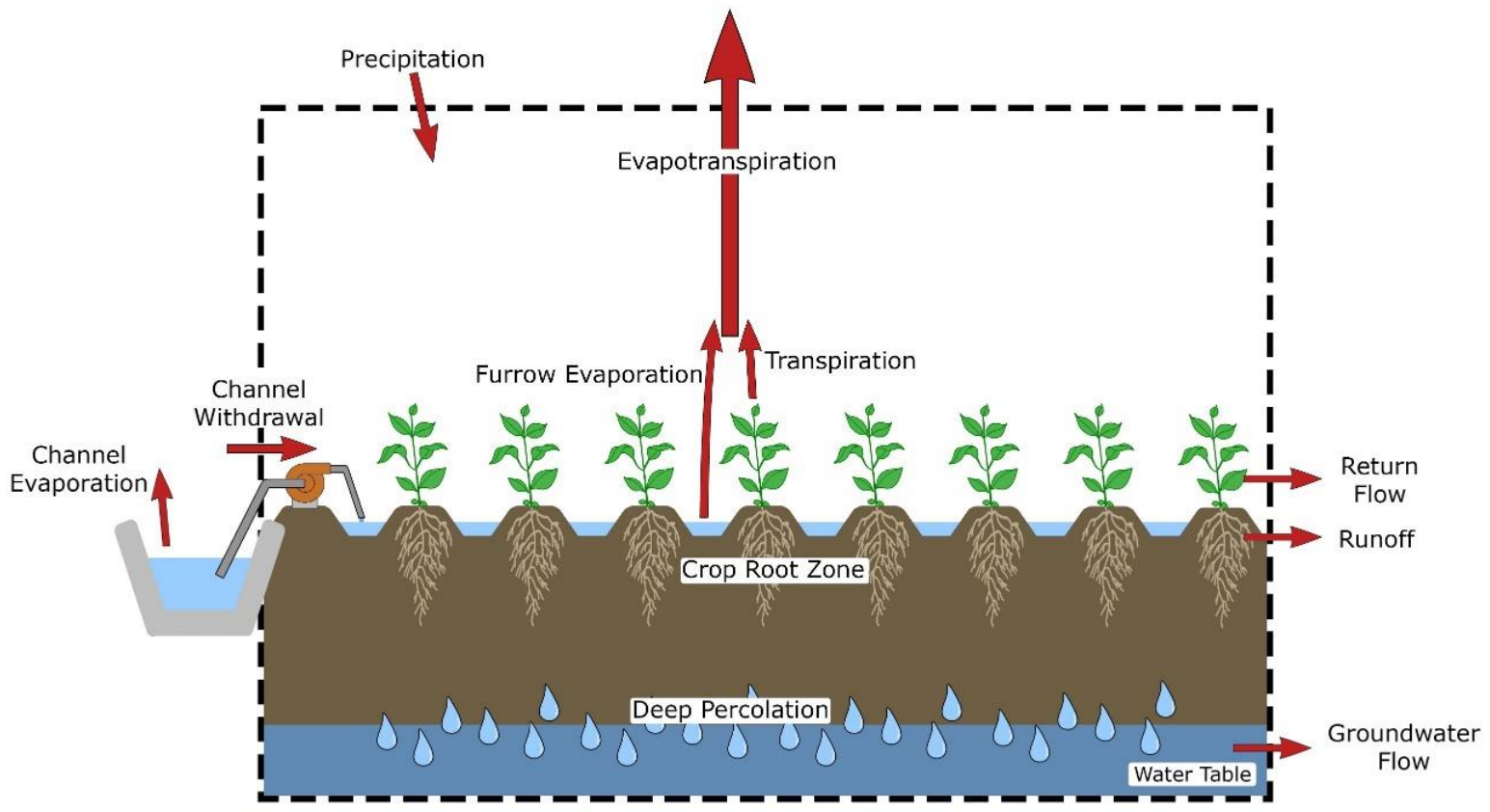

Figure 2b. Illustration of potential water flows for furrow irrigation, constrained to a field-level system (adapted from Eisenhauer et al., 2021). 
From Figures $2 \mathrm{a}$ and $2 \mathrm{~b}$, it is apparent that multiple water flows exist on a field-scale water balance, with the largest being an evapotranspiration outflow. The main idea is similar for different irrigation systems, but the specifics vary. For example, surface irrigation does not have droplet evaporation and drift, but it does have return flow which leaves the field and may be used to irrigate another field downstream. The consumptive use ratio provides a consistent way to quantify the portion of irrigation that is consumed.

Here, we define the marginal consumptive use ratio $\left(\beta^{*}\right)$ as the consumptive use ratio at a specific point on the $Y-d$ curve:

$$
\beta^{*}=\frac{\partial E T}{\partial d}
$$

We also assume that yield is directly proportional to ET:

$$
\frac{E T-E T_{n}}{E T_{f}-E T_{n}}=\frac{Y-Y_{n}}{Y_{f}-Y_{n}}
$$

Therefore, combining this with Equation 1 results in an equation for seasonal ET:

$$
E T=E T_{n}+\left(E T_{f}-E T_{n}\right)\left[1-\left(1-\frac{d}{d_{f}}\right)^{\frac{1}{\beta}}\right]
$$

Finally, similar to Martin et al. (1984), we determined the derivative of ET as a way to calculate $\beta^{*}$ based on the CobbsDouglas production function:

$$
\begin{gathered}
\beta^{*}=\frac{\partial E T}{\partial d}=\frac{\partial}{\partial d}\left\{E T_{n}+\left(E T_{f}-E T_{n}\right)\left[1-\left(1-\frac{d}{d_{f}}\right)^{\frac{1}{\beta}}\right]\right\} \\
\beta^{*}=\left(E T_{f}-E T_{n}\right)(-1) \frac{\partial}{\partial d}\left(1-\frac{d}{d_{f}}\right)^{\frac{1}{\beta}} \\
\beta^{*}=\left(1-\frac{d}{d_{f}}\right)^{\frac{1}{\beta}-1}
\end{gathered}
$$

This is significant because it provides a way to compare one irrigation scenario to another irrigation scenario $\left(\beta^{*}\right)$, instead of comparing an irrigation scenario to non-irrigated conditions $(\beta)$. Besides the Cobbs-Douglas function, we also used a simple quadratic function as an alternate method for quantifying $E T$ based on $d$ :

$$
\begin{array}{ll}
\frac{E T-E T_{n}}{E T_{f}-E T_{n}}=a d^{2}+b d+c & d \leq d_{f} \\
\frac{E T-E T_{n}}{E T_{f}-E T_{n}}=1 & d>d_{f}
\end{array}
$$


Here, $a, b$ and $c$ are parameters for fitting the equation to field data. However, the vertex of the parabola was required to occur at full yield $\left(\mathrm{d}_{\mathrm{f}}, \mathrm{ET}_{\mathrm{f}}\right)$, such that $\partial E T / \partial d=0$ at $d=d_{f}$. The marginal consumptive use ratio using the polynomial was derived and constrained to be between zero and one:

$$
\begin{array}{cc}
\beta^{*}=1 & d<\frac{1-b}{2 a} \\
\beta^{*}=2 a d+b & \frac{1-b}{2 a} \leq d \leq d_{f} \\
\beta^{*}=0 & d>d_{f}
\end{array}
$$

\section{Illustration for Deficit, Full, and Over Irrigation}

We illustrate both of these approaches (Cobbs-Douglas and polynomial) with field data from Payero et al. (2008) for subsurface-drip-irrigated maize (corn) in West-Central Nebraska. Data were collected for two growing seasons at an irrigated research field at the University of Nebraska-Lincoln's West Central Research and Extension Center in North Platte, Nebraska $\left(41.1^{\circ} \mathrm{N}, 100.8^{\circ} \mathrm{W}\right)$. This study utilized eight irrigated corn treatments between near dryland to overirrigated conditions. Data for seasonal evapotranspiration, irrigation, and yield data were used to calculate the marginal consumptive use ratio for each treatment. Full irrigation was not explicitly defined by the study, so it was determined manually at the point where no water stress occurred by selecting the trial where the ratio of actual evapotranspiration over potential evapotranspiration was closest or equal to one (i.e., $d_{f}$ and $E T_{f}$ were selected from the treatment which produced the $Y_{f}$ ).

In overirrigated conditions, the corn crop will reach a biological maximum yield where additional irrigation does not increase yields. Data from were fit to both the Cobb-Douglas function and the polynomial function. The ET was equal to the full irrigation ET when the depth of irrigation applied was greater than the depth of full irrigation $\left(E T=E T_{f}\right.$ for $\left.d>d_{f}\right)$. The vertex of the polynomial was set at the of full irrigation and evapotranspiration at full irrigation. Additionally, the vertex was the point where $\beta^{*}$ was equal to zero. Keeping the physical process in mind of the biological maximum yield at the defined vertex, and being unable to consume more than is withdrawn, $\beta^{*}$ was bounded between zero and one. The CobbDouglas and polynomial functions for $E T$ and $\beta^{*}$, along with measured data points, are shown in Figure 3.

From the figure, it can be observed that the Cobb-Douglas equation and the polynomial equations for $E T$ are quite close near the vertex; however larger discrepancies appear as depth of irrigation begins to decrease. It can also be observed that the Cobb-Douglas performs favorably at lower depths of irrigation.

In all cases, $\beta^{*}$ begins at one (when seasonal irrigation is very small) indicating that all irrigation is used for ET. Eventually, as $d$ increases, $\beta^{*}$ becomes less than one, indicating that some of the additional irrigation (marginal irrigation) goes to consumptive use but some of the marginal irrigation goes to non-consumptive losses (runoff, deep percolation, etc.). When $d$ becomes greater than $d_{f}$, none of the marginal irrigation goes to $\mathrm{ET}\left(\beta^{*}=0\right)$. In this range, any changes in irrigation which result in a reduction in $d$ will not result in a reduction in consumptive use. This illustrates our framework for evaluating the impact of new irrigation technologies on consumptive use. 



Figure 3. Observed field data from Payero et al. (2008) fit with Cobb Douglas and polynomial solutions for ET (top) and $\beta$ * (bottom). The block arrows illustrate a management range for full irrigation (correlating to full yield).

For the purposes of practical irrigation management, we consider the full irrigation range to be $d_{f} \pm 20 \mathrm{~mm}$ (illustrated with the block arrows in Figure 3). More irrigation than this would be considered the overirrigation range, while irrigation below the full irrigation range would be considered in the deficit irrigation range. 


\section{Application to Variable Rate Irrigation Technology}

\section{Methods}

To quantify the reductions of consumptive use, data collected from irrigated cropland with VRI technology were analyzed. Data from two field sites were used. One of the fields is located at the Eastern Nebraska Research and Extension Center (ENREC) near Mead, NE $\left(41.165^{\circ} \mathrm{N}, 96.430^{\circ} \mathrm{W}\right)$. This location is outfitted with a Zimmatic 8500 center pivot irrigation system by Lindsay Manufacturing (Omaha, NE) and their Precision VRI allowing individual sprinkler control across the span of system. Sprinklers on this system are mounted on the top of the lateral. The second field site for data collection was in Brule, $\mathrm{NE}\left(41.027^{\circ} \mathrm{N}, 101.973^{\circ} \mathrm{W}\right)$. This location is equipped with a similar Lindsay Zimmatic VRI center pivot sprinkler irrigation system. Treatment years for the ENREC field site included in this study were from 2015 to 2020 , while those for the Brule site included 2016-2018. Additional details about the data used for the analysis in this study are presented elsewhere: 2015-2016 (Barker et al., 2018); 2017-2018 (Barker et al., 2019; Bhatti et al., 2020); and 2019-2020 (Maguire, 2021; Singh, 2021).

Each of the field sites (ENREC $\sim 53$ ha, Brule $\sim 48$ ha) were divided into plots to facilitate the application of various irrigation scheduling treatments and treatment replications throughout the irrigation season. The common scheduling method across both locations and each treatment years, Uniform Rate Irrigation (URI), was used as the baseline for calculation of the marginal consumptive use ratio $\left(\beta^{*}\right)$. URI scheduling is, as the name implies, a uniform application rate across the research plot to maintain the soil water balance with in-season neutron probe soil moisture readings. Following this, various VRI scheduling methods were implemented across different treatment years and locations, shown in Table 1.

Table 1. Irrigation Treatments Applied Across Field Sites, Crop, and Data Collection Year.

\begin{tabular}{|c|c|c|c|c|}
\hline \multicolumn{5}{|c|}{ Field Site - Crop Treated } \\
\hline & ENREC - Maize & ENREC - Soybean & Brule - Maize & Brule - Soybean \\
\hline 2015 & URI, VRI-RS, VRI-NP & -- & -- & -- \\
\hline 2016 & URI, VRI-RS, VRI-NP & URI, VRI-RS, VRI-NP & URI, VRI-RS & -- \\
\hline 2017 & URI, VRI-L & URI, VRI-L & URI, VRI & -- \\
\hline 2018 & URI, VRI-L, VRI-U & URI, VRI-L, VRI-U & -- & $\begin{array}{c}\text { URI, VRI, URI-D, VRI- } \\
\text { D }\end{array}$ \\
\hline 2019 & $\begin{array}{l}\text { Rainfed, URI, VRI-L, } \\
\text { VRI-U, Sensor Based }\end{array}$ & $\begin{array}{l}\text { Rainfed, URI, VRI-L, } \\
\text { VRI-U, Sensor Based }\end{array}$ & -- & -- \\
\hline 2020 & $\begin{array}{l}\text { Rainfed, URI, VRI-L, } \\
\text { VRI-U, Sensor Based }\end{array}$ & $\begin{array}{l}\text { Rainfed, URI, VRI-L, } \\
\text { VRI-U, Sensor Based }\end{array}$ & -- & -- \\
\hline
\end{tabular}

The variable rate treatments are as follows:

- VRI: used exclusively at the Brule location, utilized a SETMI model with Landsat imagery inputs for irrigation scheduling,

- VRI-RS: the soil water balance was modeled utilizing remote sensing methods with irrigation depth were applied to maintain the appropriate soil water content throughout the season,

- VRI-NP: similar to VRI-RS, a modeling approach was used to maintain the soil water balance, however this model was updated with in-season neutron probe soil water content measurements in comparison to remote sensor measurements,

- VRI-L: irrigation recommendations from an outside industry-developed irrigation management software suite,

- VRI-U: similar to the VRI treatment at Brule, VRI-U utilized a SETMI model with unmanned aircraft imagery as the input data, and

- Sensor Based: data from stationary sensor nodes (equipped with over-canopy infrared thermometers and in-ground 
soil moisture sensors) located in each irrigated research plot were used for irrigation scheduling.

For the 2018 trial year at Brule, two treatments with a '-D' moniker are present, representing the same URI or VRI scheduling methodology was used, however with a deficit irrigation approach to maintain the soil water balance. Rainfed treatment included plots that were not irrigated and benefited only from seasonal precipitation. Precipitation data for the 2019 growing season was collected from four (4) Texas Electronics TR-525 USW (Dallas, Texas) tipping bucket style rain gauges placed around the ENREC location. These rainfall data were adjusted using a calibration determined for each rain gauge, and then averaged. For the 2020 season, a RealmFive-Ready Weather Front (RealmFive, Lincoln, NE) weather station was installed nearby an existing rain gauge location used in 2019.

With the data collection and analysis centered around effects of various treatment methods, a metric to compare the various irrigation treatments and impact on consumptive use was needed. First, the $\beta$ was used to compare irrigated treatments to the non-irrigated treatment. Subsequently, uniform irrigation scheduling was used as a baseline, with the intent of showing improvements in the consumptive use ratio in the VRI treatments. Equation 9 represents $\beta^{*}$, the marginal consumptive use ratio, as the difference in evapotranspiration between the challenger scheduling method and uniform scheduling method over the difference in depth of applied irrigation between the two scheduling methods.

$$
\beta^{*}=\frac{E T_{\text {Treatment }}-E T_{\text {Uniform }}}{d_{\text {Treatment }}-d_{\text {Uniform }}}
$$

\section{Results and Discussion}

Utilizing the field collected data for depth of irrigation, evapotranspiration, and yield for the various field sites, growing seasons, and irrigation treatments, data analysis was performed to verify the consumptive use ratio equation and further quantify consumptive use between each treatment.

The initial plot showing depth of irrigation applied vs. irrigated evapotranspiration includes data from the Mead, NE field site for the 2019 and 2020 crop growing seasons, shown in Figure 4. These data, including both corn and soybeans, show an average consumptive use ratio of 0.65 , equal to the slope of the trendline. For this plot, the trendline was forced to pas through the origin, as no increase in evapotranspiration would occur above the non-irrigated ET value with no applied irrigation depth (i.e., $E T_{f}=E T_{n}$ at $d=0 \mathrm{~mm}$ ). This value is lower than an expected 0.8 for an efficient sprinkler irrigated system; however, this is likely due to the inclusion of multiple irrigation scheduling techniques and climatic changes across growing seasons.



Figure 4. Change in seasonal evapotranspiration (compared to non-irrigated ET) for corn and soybean research plots, including all irrigation treatments used for the 2019 and 2020 growing seasons in Mead, NE. 
With the $\mathrm{R}^{2}$ value of 0.98 for the overall consumptive use ratio, further data analysis proceeded by calculating the marginal consumptive use ratio, $\beta^{*}$. The trendline was again forced to pass through the origin, as the full evapotranspiration and nonirrigated evapotranspiration values would be equal for no depth of irrigation applied. Figure 5 demonstrates the marginal consumptive use ratio by plotting the change in evapotranspiration versus the change in irrigation in comparison to the uniform rate irrigation treatment. Data was clustered around the origin, as most of the irrigation treatments at the Brule and Mead research locations were intended to be improved scheduling techniques with VRI.



Figure 5. Marginal irrigation versus change in evapotranspiration (marginal ET) between uniform and variable rate irrigated plots. Data shown is for points with $\triangle E T$ or $\Delta$ Irrigation greater than $10 \mathrm{~mm}$.

\section{Conclusions}

Having metrics to quantify the consumptive use of water within an irrigation system is helpful to assess the effects that different modern irrigation scheduling methods have on reductions in consumptive use. Considering consumptive uses within management practices can clarify expectations for decreased pumping and longer-term impacts on conserving water for generations to come.

\section{Acknowledgements}

The funding for this research was provided by a USGS 104(b) grant from the Nebraska Water Center, Graduate Student Support from the Robert B. Daugherty Water for Food Global Institute at the University of Nebraska, and a grant from the USDA NIFA Agricultural and Food Research Initiative (Award Number 2017-67021-26249). Additional support was received from the Hatch Act (USDA NIFA, Accession Number 1009760) and the Department of Biological Systems Engineering at the University of Nebraska-Lincoln. The authors thank Mr. Mark Schroeder and his team from the University of Nebraska's Eastern Nebraska Research and Extension Center for their cooperation and help with field operations. We also thank Alan Boldt, Mitchell S. Maguire, Sandeep Bhatti, Jasreman Singh, and Suresh Pradhyun Kashyap for their help in data collection and analysis. We especially want to thank several people for providing input on the concepts presented in this paper: Tom Riley, Director, Nebraska Department of Natural Resources; Dr. Troy Gilmore, Associate Professor, School of Natural Resources, University of Nebraska-Lincoln; and Dr. Dean Eisenhauer, Emeriti Professor, Department of Biological Systems Engineering, University of Nebraska-Lincoln. 


\section{References}

Barker, J. B., D. M. Heeren, C. M.U. Neale, and D. Rudnick. (2018). Evaluation of variable rate irrigation using a remote-sensing based model. Agricultural Water Management 203: 63-74. Doi: 10.1016/j.agwat.2018.02.022.

Barker, J. B., S. Bhatti, D. M. Heeren, C. M.U. Neale, and D. R. Rudnick. (2019). Variable rate irrigation and soybean in West-Central Nebraska under full and deficit irrigation. Frontiers in Big Data 2: 34-34. Doi: 10.3389/fdata.2019.00034.

Bhatti, S., D. M. Heeren, J. B. Barker, C. M.U. Neale, W. E. Woldt, M. Maguire, and D. R. Rudnick. (2020). Site-specific irrigation management in a sub-humid climate using a spatial evapotranspiration model with satellite and airborne imagery. Agricultural Water Management 230: Doi: 10.1016/j.agwat.2019.105950.

Eisenhauer, D. E., D. L. Martin, D. M. Heeren (General Editor), and G. J. Hoffman. (2021). Irrigation Systems Management (in press). ASABE: St. Joseph, Mich.

Evett, S. R., P. D. Colaizzi, F. R. Lamm, S. A. O’Shaughnessy, D. M. Heeren, T. J. Trout, W. L. Kranz, and X. Lin. (2020). Past, present and future of irrigation on the U.S. Great Plains. Transactions of the ASABE 63(3): 703-729, doi: 10.13031/trans.13620.

Grafton, R. Q., J. Williams, C.J. Perry, F. Molle, C. Ringler, P. Steduto, B. Udall, S.A. Wheeler, Y. Wang, D. Garrick and R.G. Allen. (2018). The paradox of irrigation efficiency. Science 361(6404): 748-750, doi: 10.1126/science.aat9314.

Kranz, W. L., Editor. (2015). Irrigation and Nitrogen Management: User Education Certificate Program. Extension Circular EC2008. Nebraska Extension: Lincoln, Nebr.

Maguire, M. S. 2021. Leveraging unmanned aerial system remote sensing to inform energy and water balance models for spatial soil water content monitoring and irrigation management. PhD Dissertation (in preparation). Department of Biological Systems Engineering, University of Nebraska-Lincoln: Lincoln, Nebr.

Martin, D. L., D. G. Watts, and J. R. Gilley. (1984). Model and production function for irrigation management. J. Irrig. Drain. Eng. 110(2): 149-164.

Martin, D. L., R. J. Supalla, C. L. Thompson, B. P. McMullen, G. W. Hergert, and P. A. Burgener. (2010). Advances in deficit irrigation management. ASABE Paper No. IRR10-9277. ASABE: St. Joseph, Mich.

Nebraska Department of Natural Resources. (2010). 2011 Annual Evaluation of Availability of Hydrologically Connected Water Supplies. Nebraska Department of Natural Resources: Lincoln, Nebr.

Payero, J.O., D. D. Tarkalson, S. Irmak, D. Davison, and J. L. Petersen. (2008). Effect of irrigation amounts applied with subsurface drip irrigation on corn evapotranspiration, yield, water use efficiency, and dry matter production in a semiarid climate. Agricultural Water Management 95: 895-908. Doi: 10.1016/j.agwat.2008.02.015

Perry, C., P. Steduto, R. G. Allen, and C. Burt. (2009). Increasing productivity in irrigated agriculture: Agronomic constraints and hydrological realities. Agricultural Water Management 96: 1517-1524. Doi: 10.1016/j.agwat.2009.05.005.

Singh, J. 2021. Sensor node station network-based unmanned aerial vehicle data mule and irrigation management for maize and soybean. PhD Dissertation (in preparation). Department of Biological Systems Engineering, University of Nebraska-Lincoln: Lincoln, Nebr. 